\title{
RANCANG BANGUN PEMBANGKIT LISTRIK TENAGA SURYA (PLTS) ON GRID DI ECOPARK ANCOL
}

\author{
Albert Gifson $^{1}$ \\ Program Studi Teknik Elektro STT PLN \\ Email: albertdoang@yahoo.co.id \\ Masbah RT Siregar ${ }^{1}$ \\ Program Studi Teknik Elektro STT PLN \\ Mohammad Priyo Pambudi ${ }^{1}$ \\ Program Studi Teknik Elektro STT PLN
}

\begin{abstract}
S : Indonesia is a tropical area that has a very large amount of sunlight which is a potential renewable energy with an average daily irradiation of $4.5-4.8 \mathrm{kWh} / \mathrm{m} 2$. As a renewable energy, sunlight is not pollutant, will not run out, but is free or free. Therefore this energy source can be utilized for electricity through the Solar Power Plant (PLTS) system. This research will discuss the design of On Grid Solar Power Generation (PLTS) systems by generating 60\% of the load capacity in the Learning Farm area. The power generated is $68.17 \mathrm{kWp}$ using 100 solar cell modules. This PLTS is designed to reduce electricity consumption from PLN in Ancol Ecopark. This location is considered to have good solar radiation potential and a large availability of land. The results of this design are expected to be a reference for the Ancol ecopark learning farm in order to obtain a good match between energy needs, price, and quality.

Keyword: renewable energy, ecopark, PLTS.
\end{abstract}

ABSTRAK: Indonesia merupakan daerah tropis yang mempunyai sinar matahari yang sangat besar menjadi potensi energi terbarukan dengan iradiasi harian rata-rata $4,5-4,8 \mathrm{kWh} / \mathrm{m}^{2}$. Sebagai energi terbarukan, sinar matahari tidak bersifat polutif, tidak akan habis, namun bersifat gratis atau cuma-cuma. Maka dari itu sumber energi ini dapat dimanfaatkan untuk kelistrikan melalui sistem Pembangkit Listrik Tenaga Surya (PLTS). Pada penelitian ini akan dibahas perancangan sistem Pembangkit Listrik Tenaga Surya (PLTS) On Grid dengan membangkitkan $60 \%$ dari kapasitas beban di area Learning Farm. Besar daya yang dibangkitkan sebesar $68,17 \mathrm{kWp}$ dengan menggunakan 100 modul sel surya. PLTS ini dirancang untuk mengurangi pemakaian listrik dari PLN di Ecopark Ancol. Lokasi ini dinilai memiliki potensi radiasi matahari yang cukup baik dan ketersediaan lahan yang luas. Hasil dari perancangan ini diharapkan menjadi acuan bagi pihak ecopark learning farm Ancol agar diperoleh kesesuaian antara kebutuhan energi, harga, dan kualitas yang baik.

Kata Kunci: energi terbarukan, ecopark, PLTS.

\section{PENDAHULUAN}

Dembangkit Listrik Tenaga Surya (PLTS) adalah sistem pembangkit listrik yang memanfaatkan energi matahari untuk menjadi energi listrik melalui photovoltaic module yang termasuk dalam energi hijau sehingga menjadi suatu pembangkit yang terbarukan, lebih efisien efektif, handal dan dapat mensuplai kebutuhan energi listrik. PLTS merupakan salah satu sarana untuk memenuhi kebutuhan masyarakat akan listrik yang sangat ramah lingkungan. Mengingat Indonesia merupakan daerah tropis, maka sangatlah baik apabila PLTS dikembangkan dengan sungguh-sungguh.

Berdasarkan uraian di atas, penulis bermaksud memberikan sumbangan pemikiran penggunaan PLTS di ecopark pada area learning farm atau taman belajar untuk mengurangi pemakaian listrik dari PLN yaitu untuk berlangsungnya kegiatan utama pada area learning farm. Oleh karena itu, penulis akan membuat sebuah penelitian tentang Rancang Bangun Pembangkit Listrik Tenaga Surya (PLTS) On Grid di ecopark Ancol pada area Learning Farm.

Saat ini, Allianz ecopark Ancol adalah kawasan rekreasi terbaru yang menawarkan nilai - nilai edukasi dan petualangan dengan pendekatan green lifestyle. Ecopark ini terbagi menjadi beberapa kawasan dengan fungsi dan fasilitas berbeda, yang mempunyai luas sekitar 34 Hektar, masih banyak tersedia lahan kosong yang dapat dimanfaatkan untuk dipasangi pembangkit listrik tenaga surya. Dimana nantinya, taman wisata ini selain dimanfaatkan untuk rekreasi/edukasi, PLTS nya dapat dimanfaatkan pula sebagai penambahan materi edukasi dan objek penelitian.

\footnotetext{
1 Sekolah Tinggi Teknik PLN
} 
Berdasarkan identifikasi uraian diatas, maka permasalahan yang akan dibahas adalah:

1. Berapa besar daya yang dihasilkan pada ecopark ?

2. Bagaimana rangkaian PLTS yang akan dibangun?

3. Komponen apa saja yang digunakan dalam rancang bangun ecopark ini ?

Penelitian sebelumnya mengenai studi terhadap unjuk kerja PLTS 1920 Watt di Universitas Udayana Bukit Jimbaran. Penelitian membahas konfigurasi eksisting optimal PLTS dan unjuk kerja PLTS tersebut. PLTS di Fakultas Teknik Bukit Jimbaran merupakan paket PLTS off-grid. Penelitian tersebut menghasilkan beberapa data, yaitu konfigurasi PV modul yang terhubung untuk menyuplai baterai sebanyak $32 \mathrm{PV}$ modul, unit baterai dengan kapasitas sebesar $1455 \mathrm{Ah} \approx 15$ unit baterai dengan kapasitas baterai $100 \mathrm{Ah}$, unit baterai charge controller dengan kapasitas load current sebesar 20 A sebanyak 4 buah, dan kapasitas inverter yang digunakan $6000 \mathrm{~W}$ dengan efisiensi $90 \%$. Ada juga penelitian lain tentang Studi Perencanaan Pembangkit Listrik Tenaga Surya On Grid $30 \mathrm{kWp}$ di Taman Wisata Angke Kapuk. Penelitian tersebut membahas tentang kajian teknis dan ekonomis perencanaan PLTS on grid untuk menyuplai kebutuhan listrik di Taman Wisata Angke Kapuk. Perencanaan tersebut membutuhkan 3 array panel surya dengan total 150 panel dan 3 unit inverter.

Penggunaan PLTS pada ecopark Ancol di area learning farm bertujuan untuk penyuplai listrik dan sarana edukasi energi terbarukan yang sangat ramah lingkungan. Mengingat Indonesia merupakan daerah tropis, maka sangatlah baik jika PLTS dikembangkan dengan sungguh-sungguh. Karena PLTS adalah bentuk investasi jangka panjang, ditambah dengan biaya perawatan PLTS yang murah, akan menguntungkan bagi ecopark Ancol. Untuk lebih jelasnya, sistem PLTS pada area learning farm dapat dilihat pada gambar 1 berikut ini.

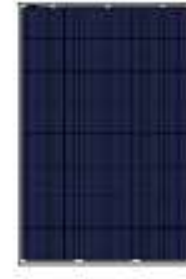

Array
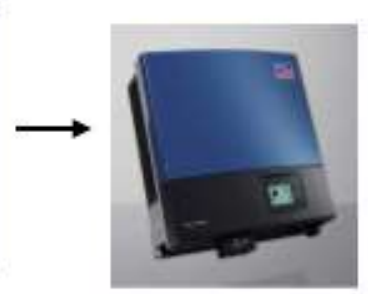

inverter

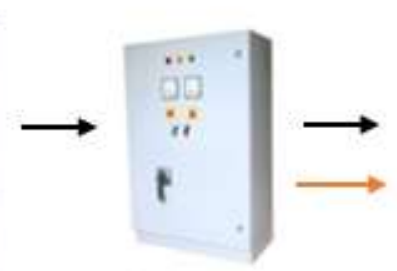

Measurement

Box
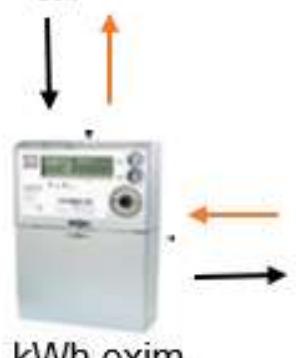

kWh exim

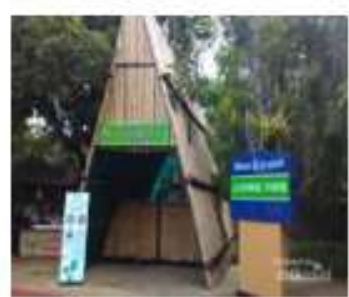

load

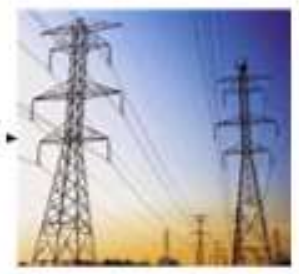

PLN

- Gambar 1. Blok Diagram On Grid 


\section{METODOLOGI}

Metode dan tahapan penelitian ini menggunakan sifat penelitian eksperimental yang mengacu pada metode kuantitatif dengan perancangan analisa kebutuhan daya listrik menggunakan PLTS di ecopark Ancol, melalui pendekatan perhitungan dan pengukuran dan menerapkan pada rancang bangun rangkaian dan komponen PLTS yang akan digunakan di ecopark Ancol.

Berikut merupakan diagram alir penelitian untuk mempermudah pemahaman yang dilakukan di dalam penelitian ini, yaitu :

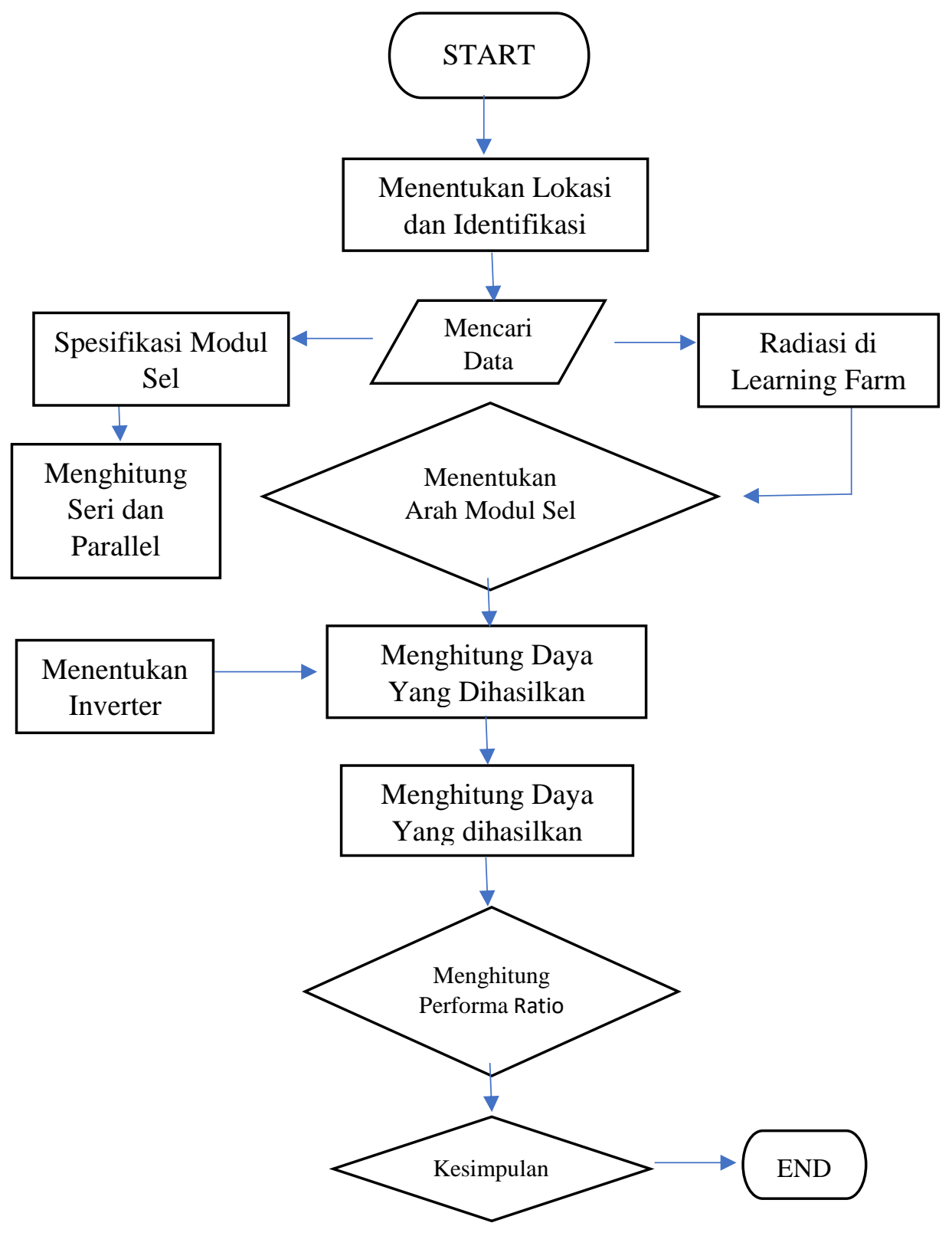

Gambar 2. Diagram alir penelitian

\section{Lokasi PLTS}

Taman Impian Jaya Ancol, JL. Lodan Timur No. 7, RW 10, Kota Tua, Ancol, Jakarta Utara, Kota Jakarta Utara, Daerah Khusus Ibu Kota Jakarta dengan koordinat 6 07’27’'S 106 50’13”E. 


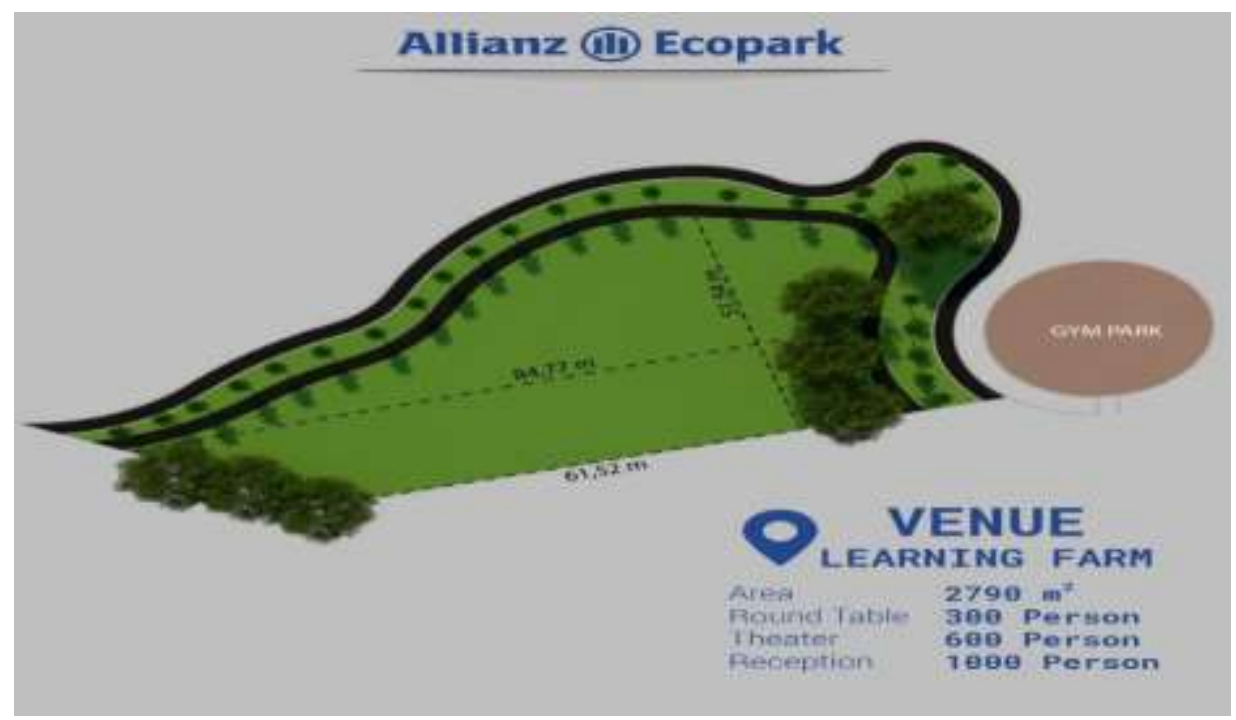

Gambar 3. Area Pembangunan PLTS di Ecopark Ancol

2. Spesifikasi komponen yang digunakan

a. Modul Surya Jsky $200 \mathrm{Wp}$ Polycrystalline

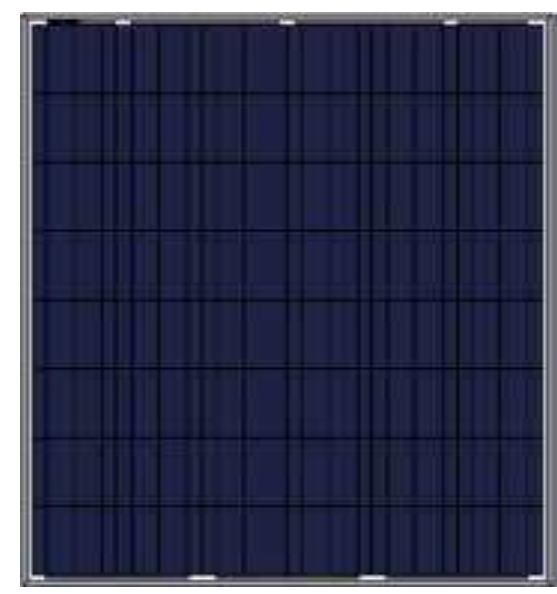

Gambar 4. Jsky Solar Panel 200 Wp

Faktor-faktor yang mempengaruhi kinerja modul sel surya antara lain sebagai berikut:

1. Suhu modul

Sebuah panel surya dapat beroperasi secara maksimal jika suhu panel tetap normal pada suhu $25^{\circ} \mathrm{C}$. Kenaikan suhu lebih tinggi dari suhu normal pada panel surya akan melemahkan tegangan open circuit (Voc) yang dihasilkan. Setiap kenaikan suhu surya $1^{\circ} \mathrm{C}$ (dari $25^{\circ} \mathrm{C}$ ) akan mengakibatkan berkurangnya daya yang dihasilkan sekitar 0,5\% (Schaeer: 1990). Menghitung besarnya daya yang berkurang pada saat suhu di sekitar panel mengalami kenaikan ${ }^{\circ} \mathrm{C}$ dari suhu standar, menggunakan persamaan (1):

$P_{\text {saat t naik }}^{\circ}{ }^{\circ} \mathrm{C}=0,5 \%$ per $^{\circ} \mathrm{C} \times P_{M P P} \times \Delta t$

Dimana:

$\mathrm{P}_{\text {saat } \mathrm{t} \text { naik }}{ }^{\circ} \mathrm{C} \quad$ : daya pada saat suhu naik ${ }^{\circ} \mathrm{C}$ dari suhu standar

$\mathrm{P}_{M P P} \quad$ : daya keluaran maksimal modul surya

$\Delta \mathrm{t} \quad$ : kenaikan suhu 
Daya keluaran maksimum panel surya pada saat suhu naik menjadi $\mathrm{t}^{\circ} \mathrm{C}$ dari suhu standar dihitung dengan persamaan (2):

$$
P_{M P P \text { saat naik menjadi }{ }^{\circ} \mathrm{C}}=P_{M P P}-P_{\text {saat } t \text { naik }}{ }^{\circ} \mathrm{C}
$$

$\mathrm{P}_{M P P}$ saat $\mathrm{t}$ naik menjadi $\mathrm{t}{ }^{\circ} \mathrm{C}$ adalah daya keluaran maksimum panel surya pada saat suhu di sekitar panel naik menjadi t ${ }^{\circ} \mathrm{C}$ dari suhu standar. Faktor koreksi temperatur (Themperatur Correction Factor) dihitung dengan persamaan (3):

$$
T C F=\frac{P_{M P P \text { saat naik menjadi }{ }^{\circ} C}}{P_{M P P}}
$$

\section{Intensitas Cahaya Matahari}

Radiasi matahari di bumi pada lokasi yang berbeda akan bervariasi dan sangat bergantung dengan keadaan spektrum matahari ke bumi. Radiasi matahari akan berpengaruh terhadap daya yang dikeluarkan oleh panel.

\section{Kecepatan tiupan angin}

Kecepatan tiupan angin di sekitar lokasi panel surya akan sangat membantu terhadap pendinginan suhu permukaan panel sehingga suhu dapat terjaga di kisaran suhu yang kondusif.

\section{Keadaan atmosfir bumi}

Keadaan atmosfir bumi berawan, mendung, jenis debu udara, asap, uap air, kabut dan polusi sangat menentukan kinerja dari panel surya.

\section{Peletakan panel surya}

Agar energi matahari yang diserap berada pada nilai yang optimal maka permukaan panel surya harus dipertahankan tegak lurus terhadap sinar matahari yang jatuh ke permukaan panel surya. Oleh karena itu peletakan panel surya sangat penting agar kinerja panel surya maksimal.

b. Spesifikasi inverter

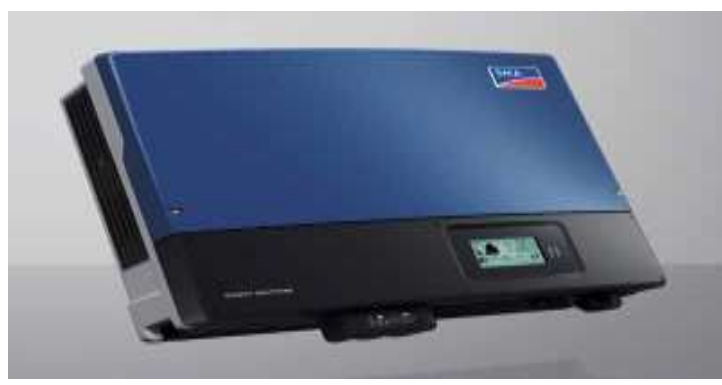

Gambar 5. Inverter SMA Sunnyboy

\section{Menghitung Area Array (PV Area)}

Luas area array diperhitungkan dengan menggunakan persamaan sebagai berikut:

$$
P V_{\text {Area }}=\frac{W}{G_{a v} \times \eta_{p v} \times T C F \times \eta_{o u t}}
$$

Dimana :

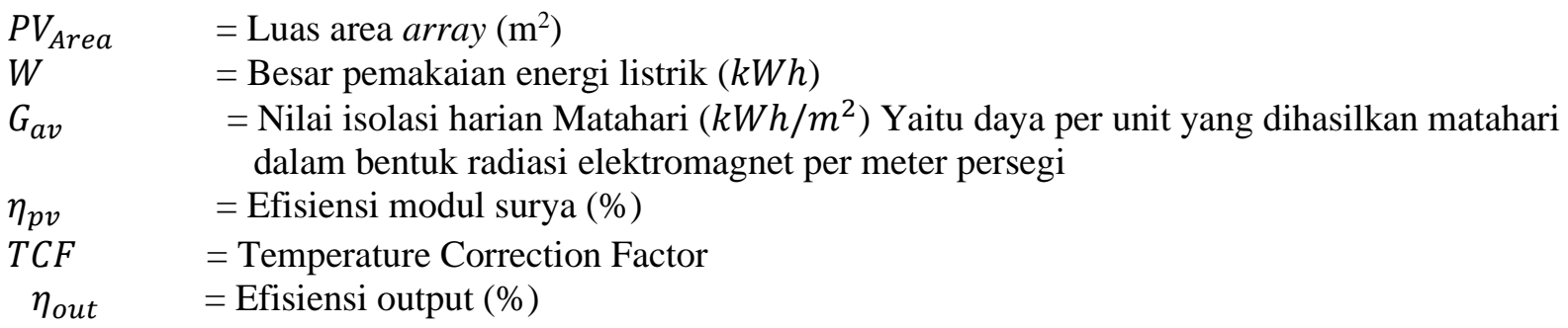




\section{Menghitung Daya yang Dibangkitkan PLTS (Watt-peak)}

Dari perhitungan area array, maka besar daya yang dibangkitkan PLTS (Watt Peak) dapat dihitung dengan persamaan sebagai berikut :

$$
P \text { Watt peak }=\text { area array } \times \text { PSI } x \mathrm{npv}
$$

Dimana :

$\mathrm{P}_{\text {wattpeak }} \quad=$ Besar daya yang dibangkitkan PLTS (Wattpeak)

PSI $\quad=$ Peak Sun Insolation $(\mathrm{PSI})$ adalah $1000 \mathrm{~W} / \mathrm{m}^{2}$

5. Menghitung Jumlah Modul Sel Surya

Dalam menentukan jumlah modul sel surya yang akan digunakan, ditentukan dengan persamaan sebagai berikut:

$$
\text { Jumlah Panel Surya }=\frac{P_{\text {Watt } p e a k}}{P_{M P P}}
$$

Dimana :

$\mathrm{P}_{\mathrm{MPP}} \quad=$ Daya maksimum panel surya yang digunakan $(\mathrm{W})$

$\mathrm{P}_{\text {Wattpeak }}=$ Daya yang dibangkitkan $(\mathrm{Wp})$

Untuk memperoleh besar tegangan, arus dan daya yang sesuai dengan kebutuhan, maka modul sel surya tersebut harus dikombinasikan secara seri dan paralel dengan aturan sebagai berikut:

a. Untuk memperoleh tegangan keluaran yang lebih besar dari tegangan keluaran panel surya, maka dua buah (lebih) panel surya dihubungkan secara seri.

b. Untuk memperoleh arus keluaran yang lebih besar dari arus keluaran panel surya, maka dua buah (lebih) panel surya dihubungkan secara paralel.

c. Untuk memperoleh daya keluaran yang lebih besar dari daya keluaran panel surya dengan tegangan yang konstan maka panel-panel surya dihubungkan secara seri dan paralel.

6. Menentukan Kapasitas Inverter

Spesifikasi inverter disesuaikan dengan charge controller yang digunakan. Tegangan masuk (input) dan tegangan keluar (output) dari inverter diketahui berdasarkan tegangan sistem dan nominal tegangan AC yang digunakan, yakni 220 Volt.

7. Menentukan Rangkain (Pengaturan Seri-Paralel) Panel Surya

1. Secara seri minimal

$$
\text { Min modul seri per string }=\frac{\text { Vmin inverter }}{\text { Voc modul }}
$$

2. Secara seri maximal

$$
\text { Max modul seri per string }=\frac{\text { Vmin inverter }}{\text { Vmp modul }}
$$

3. Secara paralel

$$
\begin{aligned}
& \text { Max } \text { Paralel }=\frac{\text { Imax Input Inverter }}{\text { Imp modul }} \\
& \begin{array}{ll}
\text { Dimana : } & \\
\text { Voc } & \text { Tegangan Open Circuit dari modul surya (Volt) } \\
\text { Vmp inverter } & \text { : Tegangan kerja minimal dari inverter (Volt) } \\
\text { Vmax inverter } & \text { : Tegangan maksimal dari inverter (Volt) } \\
\text { Imp modul } & \text { : Arus dari modul surya (Amp) } \\
\text { Imax input inverter } & \text { : Arus masuk pada inverter (Amp) }
\end{array}
\end{aligned}
$$




\section{HASIL DAN PEMBAHASAN}

1. Analisa Pemakaian Beban

Setelah memperoleh data spesifikasi alat dan data penggunaan beban maka dapat dihitung kebutuhan beban per hari seperti berikut :

Tabel 1. Pemakaian Beban Area Learning Farm

\begin{tabular}{|c|c|c|c|c|c|}
\hline Beban & $\begin{array}{l}\text { Daya } \\
\text { (W) }\end{array}$ & $\begin{array}{l}\text { Quantity } \\
\text { (Pcs) }\end{array}$ & $\begin{array}{l}\text { Total Daya } \\
\text { (W) }\end{array}$ & $\begin{array}{c}\text { Lama } \\
\text { Pemakaian } \\
(\mathrm{H})\end{array}$ & $\begin{array}{l}\text { Konsumsi } \\
\text { Energi (Wh) }\end{array}$ \\
\hline Lampu TL & 40 & 40 & 1600 & 12 & 19.200 \\
\hline $\begin{array}{c}\text { Bohlam LED } \\
\text { Philips }\end{array}$ & 18 & 4 & 72 & 12 & 864 \\
\hline Essential & 80 & 2 & 160 & 8 & 1.280 \\
\hline HPIT & 400 & 12 & 4800 & 8 & 38.400 \\
\hline Kipas Angin & 50 & 6 & 300 & 8 & 2.400 \\
\hline Speaker Aktif & 175 & 2 & 350 & 9 & 3.150 \\
\hline Amplifier & 1600 & 2 & 3200 & 9 & 28.800 \\
\hline Amplifier Toa & 200 & 1 & 200 & 6 & 1.200 \\
\hline Pompa Sanyo & 250 & 2 & 500 & 6 & 3.000 \\
\hline Pompa Shoufou & 370 & 3 & 1110 & 6 & 6.660 \\
\hline Peralatan Lainnya & 1000 & 1 & 1000 & 10 & 10.000 \\
\hline \multicolumn{3}{|c|}{ Total } & 13.292 & \multicolumn{2}{|c|}{$114,954 \mathrm{KWh}$} \\
\hline
\end{tabular}

Penggunaan beban yang akan direncanakan dalam perencaannaan ini akan digunakan $60 \%$ untuk perencanaan PLTSnya, dikarenakan Agar biaya investasi tidak terlalu besar, rancangan hanya sebatas mengurangi total beban listrik.

\section{Menentukan Kapasitas PV Modul}

Untuk menentukan kapasitas modul surya yang diinginkan, maka perlu ditetapkan beban yang benar-benar diinginkan, yaitu sebesar $60 \%$ dari total beban yang digunakan, maka dapat dihitung sebagai berikut:

$$
\begin{aligned}
\text { Beban } & =60 \% \mathrm{X} \text { total beban } \\
= & 60 \% \mathrm{X} 114,954 \mathrm{KWh} \\
& =68,97 \mathrm{Kwh}
\end{aligned}
$$


Jika beban sudah diketahui, maka perlu dihitung berapa luas PV area yang digunakan, maka dapat dilakukan perhitungan sebagai berikut:

$$
P V_{\text {Area }}=\frac{W}{G_{a v} \times \eta_{p v} \times T C F \times \eta_{\text {out }}}
$$

Sesuai dengan ketentuan yang berlaku, panel surya memiliki penurunan kapasitas daya yang dihasilkan jika melebihi dari standar suhu optimal panel surya tersebut bekerja. Jika panel surya tersebut bekerja diatas suhu $25{ }^{\circ} \mathrm{C}$ maka akan berkurang $0.5 \%$ setiap perubahan suhunya. Suhu tertinggi $29,82^{\circ} \mathrm{C}$ pada bulan april dan suhu terendah $25,15^{\circ} \mathrm{C}$ pada bulan januari, maka kenaikannya menjadi $4.82^{\circ} \mathrm{C}$. maka dapat dihitung dengan persamaan (1) sebagai berikut:

$$
\begin{aligned}
\text { P saat naik } 4,82{ }^{\circ} \mathrm{C} & =0,5 \% /{ }^{\circ} \mathrm{C} \times P_{M P P} \times \text { kenaikan }{ }^{\circ} \mathrm{C} \\
& =0,5 \% /{ }^{\circ} \mathrm{C} \times 200 \mathrm{~W} \times 4,82{ }^{\circ} \mathrm{C} \\
& =4,82 \mathrm{~W}
\end{aligned}
$$

Keluaran daya saat temperature naik menjadi $29,82^{\circ} \mathrm{C}$ dapat dihitung dengan persamaan (2) dan (3) menjadi $\mathrm{P}_{\mathrm{MPP}}$ saat naik temperature ${ }^{\circ} \mathrm{C}=\mathrm{P}_{\mathrm{MPP}}$ - Psaat temperatur ${ }^{\circ} \mathrm{C}$ naik:

$$
\begin{array}{r}
29,82{ }^{\circ} \mathrm{C}=200 \mathrm{~W}-4,82 \mathrm{~W} \\
=195.18 \mathrm{~W} \\
T C F=\frac{195,18}{200} x 100=0,97
\end{array}
$$

Jika telah diketahui semuanya, maka dilakukan perhitungan menentukan kapasitas PV area keseluruhan dengan persamaan (4) sebagai berikut:

$$
\begin{aligned}
P V \text { area }=P V \text { area }= & \frac{E l}{\text { Gav } \times \eta P V \times T C F \times \eta o u t} \\
& =\frac{68,97 \mathrm{Kwh}}{4,01 \frac{\mathrm{kwh}}{\mathrm{m}^{2}} \times 0,153 \times 0,97 \times 0,9}=128,77 \mathrm{~m}^{2} \\
& =130 \mathrm{~m}^{2}
\end{aligned}
$$

3. Menghitung daya yang dibangkitkan

Dari perhitungan area array, maka besar daya yang dibangkitkan PLTS (Watt-peak) dapat dihitung dengan persamaan (5). Dengan area array adalah $130 \mathrm{~m}^{2}$, Peak Sun Insolation (PSI) adalah $1000 \mathrm{~W} / \mathrm{m}^{2}$ dan efisiensi modul surya adalah $15,30 \%$ maka:

$$
\begin{aligned}
\mathrm{P} \text { watt peak } & =\text { area array } \times \text { PSI } \mathrm{npv} \\
& =130 \mathrm{~m}^{2} \times 1000 \mathrm{~W} / \mathrm{m}^{2} \times 0,153 \\
& =19.890 \mathrm{~W}
\end{aligned}
$$

4. Menentukan Jumlah Modul Sel Surya

Modul sel surya yang akan digunakan pada perencanaan sistem ini memiliki kapasitas $\mathrm{P}_{\text {MPP }}$ sebesar $200 \mathrm{Wp}$ per modul. Berdasarkan nilai tersebut, maka jumlah modul sel surya yang dibutuhkan sistem ini dapat dihitung dengan persamaan (6):

$$
=\frac{P \text { watt peak }}{\text { Pmpp }}=\frac{19.890 \mathrm{~W}}{200 \mathrm{~W}}=99,4=100 \text { panel }
$$


Penentuan rangkaian ini dilakukan untuk mengetahui besar daya yang dikeluarkan panel surya secara keseluruhan, jika untuk memperbesar arus maka dilakukan pemasangan secara parallel, dan jika ingin memperbesar tegangan maka perlu dirangkai secara seri, adapun perhitungannya sebagai berikut:

Diketahui:

Open Circuit Voltage ( Voc)

Maximum Power Voltage ( Vmp )

Maximum Power Current ( Imp )

Maximum System Voltage

Minimum System Voltage

Pengaturan Seri-Paralel Panel Surya

1. Secara seri minimal

$$
\text { Min modul seri per string }=\frac{150 \mathrm{~V}}{29,8 \mathrm{~V}}=\approx 6 \text { panel }
$$

2. Secara seri maximal

3. Secara paralel

$$
\text { Max modul seri per string }=\frac{1000 \mathrm{~V}}{24,6 \mathrm{~V}}=44 \text { panel }
$$

$$
\text { Max Paralel }=\frac{33 A}{8,73 A}=3,78 \approx 4 \text { panel }
$$
adalah:

Dengan demikian tegangan dan arus maksimum yang mampu di keluarkan dari array tersebut

$$
\begin{aligned}
25 \mathrm{x} \operatorname{Vmax} & =25 \times 24.6 \\
& =615 \mathrm{~V} \\
2 \times \operatorname{Imax} & =2 \times 8,14 \\
& =16,28 \mathrm{~A}
\end{aligned}
$$

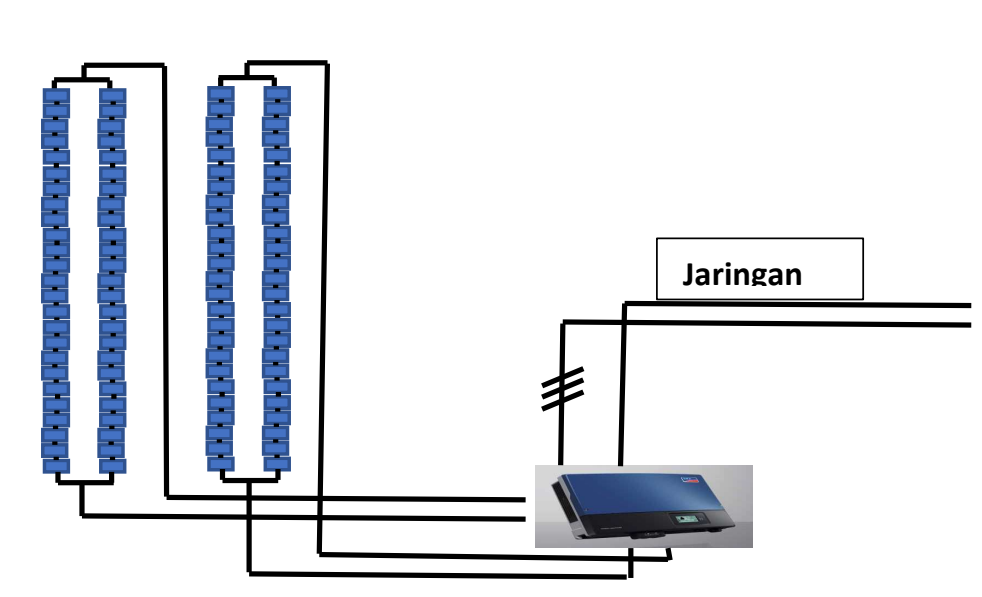

Gambar 6. Rancangan PLTS di Learning Farm

6. Menentukan Kapasitas Inverter

Dari perhitungan tentang seri dan parallel diatas, maka inverter yang digunakan sebanyak 1 buah untuk dua array, karena rangkaian modul suryanya dirangkai dengan ketentuan dari nilai sistem inverter tersebut, dan panel surya yang dirangkai secara seri minimum 6 panel dan maksimum 44 panel, serta rangkaian paralelnya tidak lebih dari 4 panel.

\section{Menghitung Besar Daya Keluaran PLTS}

Asumsi rugi-rugi (losses) sistem PLTS 15\% karena keseluruhan komponen sistem yang digunakan masih baru (Bien, Kasim, \& Wibowo, 2008:41 dalam bukunya Mark Hankins, 1991:68), losses terjadi karena beberapa faktor seperti kotoran (debu), temperatur, dan kabel penghantar sebesar $\pm 10 \%$ 
dan factory losses 5\%. Sehingga besar energi dari panel surya tesebut di kurangi dengan besar losses seperti perhitungan berikut :

$$
100 \text { panel surya } \times 200 \mathrm{Watt}=20000 \approx 20 \mathrm{~kW}
$$

Dengan losses $15 \%$ maka output dari PLTS yaitu:

Losses $=$ besar daya terpasang $\times 15 \%$

$$
\begin{aligned}
& =20 \mathrm{~kW} \times 15 \%=3000 \mathrm{~W} \\
& P_{i}=\text { besar daya yang digunakan } \times(100 \%-15 \%) \\
& =20000 \mathrm{watt} \times 3000 \mathrm{~W}=17000 \mathrm{~W} \approx 17 \mathrm{~kW}
\end{aligned}
$$

Hasil dari pengurangan losses pada panel surya berdasarkan kapasitas panel yang terpasang adalah sebesar $17 \mathrm{~kW}$. Berikut ini akan dianalisa energi yang dihasilkan oleh modul surya berkaitan dengan data radiasi matahari yang terendah dan yang tertinggi. Apabila data yang digunakan adalah radiasi matahari terendah 4,01 maka energi yang dihasilkan PLTS dapat dihitung sebagai berikut:

$$
\begin{gathered}
P_{\text {out }}=P_{i} \times \text { Radiasi matahari minimum } \\
=17 \mathrm{~kW} \times 4.01 \mathrm{~h} \\
=68,17 \mathrm{kWh}
\end{gathered}
$$

Jadi, energi yang dihasilkan PLTS pada saat radiasi matahari terendah adalah 68,17 kWh.

Jika menggunakan data radiasi matahari tertinggi yaitu 6,61 maka :

$$
\begin{aligned}
P_{\text {out }} & =P_{i} \times \text { Radiasi matahari maximum } \\
& =17 \mathrm{~kW} \times 6.61 \mathrm{~h}=112,37 \mathrm{kWh}
\end{aligned}
$$

Jadi, energi yang dihasilkan PLTS pada saat radiasi matahari tertinggi adalah $112,37 \mathrm{kWh}$.

Jika ingin menghitung energi yang dihasilkan rata rata pertahun, maka data radiasi yang digunakan adalah radiasi rata rata, atau disebut Peak Sun Hour (PSH) dengan nilai 5,175.

$$
\begin{aligned}
P_{\text {out }} & =P_{i} \times P S H \\
& =17 \mathrm{~kW} \times 5,175 \mathrm{~h} \\
& =87.98 \mathrm{kWh}
\end{aligned}
$$

Energi yield $=$ energi output $x 365$ hari

Energi yield $=87.98 \mathrm{kWh} \times 365$ hari $=32.113 \mathrm{kWh} /$ tahun .

- Tabel 2. Hasil perhitungan radiasi matahari dan Energi yield

\begin{tabular}{|c|c|c|c|}
\hline \multicolumn{2}{|c|}{ Radiasi Matahari } & \multicolumn{2}{|c|}{ Radiasi Matahari } \\
Terendah (kWh) & Tertinggi (kWh) & Radiasi Matahari & Eyield \\
\hline 68,17 & 112,37 & 87,98 & 32.113 \\
\hline
\end{tabular}

8. Menghitung Performance Ratio (PR)

Performance Ratio (PR) adalah ukuran suatu kualitas sistem dilihat dari energi tahunan yang dihasilkan. Apabila sistem tersebut nilai PR nya berkisar 70-90\%, maka sistem tersebut dapat dikatakan layak. Berikut perhitungan untuk mencari nilai performance ratio dari sistem PLTS ini :

$$
\begin{gathered}
P R=\frac{E \text { yield }}{\text { Eideal }}, \\
\text { E ideal }=\text { P array_STC } \times H_{\text {tilt }} \\
H_{\text {tilt }}=\text { PSH } \times 365=\left(5,175 h \times \frac{1000 \mathrm{~W}}{\mathrm{~m} 2}\right) \times 365 \text { hari }=1888,87 \mathrm{kWh} / \mathrm{m} 2
\end{gathered}
$$




$$
\begin{aligned}
& \text { Energi ideal }=\text { daya spesifikasi modul surya } \times \text { jumlah modul } x H_{\text {tilt }} \\
& \begin{aligned}
\text { Energi ideal }= & 200 \mathrm{Wp} \times 100 \text { modul } \times 1888,87 \frac{\mathrm{h}}{\text { tahun }} \\
& =37.777 .400 \mathrm{Wh} / \text { tahun }
\end{aligned}
\end{aligned}
$$

Sehingga diperoleh PR, sebesar :

$$
\begin{aligned}
& P R=\frac{E \text { yield }}{\text { Eideal }} \\
& P R=\frac{32.113 \mathrm{kWh} / \text { tahun }}{37.777 .400 \mathrm{Wh} / \text { tahun }}=0.85 \approx 85 \%
\end{aligned}
$$

Jadi, dari hasil perhitungan performa ratio diatas didapat ratio sebesar $85 \%$

\section{KESIMPULAN}

1. Rancang bangun Pembangkit Listrik Tenaga Surya (PLTS) di Allianz Ecopark Ancol pada area Learning Farm dilakukan dengan sistem On Grid, sistem ini dipilih untuk mengurangi pemakaian listrik dari PLN. Dengan daya keluaran yang dihasilkan pada radiasi terendah $68,17 \mathrm{kWh}$, radiasi tertinggi $112,37 \mathrm{kWh}$, dan radiasi rata-rata $87,98 \mathrm{kWh}$. Jadi rancang bangun PLTS on grid ini dapat membangkitkan $60 \%$ dari kapasitas beban yaitu pada daya $68,17 \mathrm{kWh}$.

2. Dari 100 panel surya yang digunakan, terdapat 4 string dengan 25 panel surya di pasang secara seri dan 2 panel di pasang secara parallel. Jumlah array yang terpasang 2 yang kemudian terhubung ke inverter SMA Sunny Boy 20000TL. Inverter SMA Sunny Boy 20000TL kemudian terhubung ke panel dan diteruskan beban dan jaringan PLN.

3. Komponen sistem PLTS On Grid yang diperlukan di Allianz Ecopark Ancol pada area Learning Farm yaitu satu inverter SMA Sunny boy 20000TL, dan panel surya sebanyak 100 dengan kapasitas $200 \mathrm{Wp}$.

\section{DAFTAR PUSTAKA}

[1] I.W.G.A Anggara, I.N.S Kumara (2014). "Studi Terhadap Unjuk Kerja Pembangkit Listrik Tenaga Surya 1920 Watt Di Universitas Udayana Bukit Jimbaran”, E-Journal Spektrum Vol.1 No.1

[2] Imaduddin Marie Gindo, Heri Suyanto "Studi Perencanaan On Grid Dengan Kapasitas 30 kWp Di Taman Wisata Angke Kapuk”, STTPLN, Oktober 2019.

[3] Liu, Y.H., Liu, C.-L., Huang, J.-W.,\& Chen, J-H. (2013). Neural-Network-Based Maximum Power Point Tracking Methods For Photovoltaic System Operation Under Fast Charging Environment. Solar Energy, 89, 42-53.

[4] Dwi Ratna Ningsih,"Perencanaan Pembangkit Listrik Tenaga Surya Rooftop 30 kWp Di Gedung Bapeda Propinsi Kaltim", STTPLN, Agustus 2016.

[5] Fajri Hakim, "Perancangan Rooftop Off Grid Solar Panel Pada Rumah Tinggal Sebagai Alternatif Sumber Energi Listrik", Jurnal Politeknik Negeri Malang, 2017

[6] Ramadhani Ing Bagus, "Instalasi Pembangkit Listrik Tenaga Surya, Dos and Don't", Kementrian Energi dan Sumber Daya Mineral, 2018

[7] Sianipar, Rafael. 2014. "Dasar Perencanaan Pembangkit Listrik Tenaga Surya”, Jurnal. Jakarta : Universitas Trisakti.

[8] ....., "Suneon Roman Tile roof mounting system", www.suneonsolar.com, Diakses pada tanggal 27 Juli 2018 pukul 11.00 WIB. 